\title{
Article
}

\section{Dentists' Opinions in Providing Oral Healthcare to Elderly People: A Questionnaire-Based Online Cross-Sectional Survey}

\author{
Daria Madunic ${ }^{1}$, Lidia Gavic ${ }^{1}$, Ivan Kovacic ${ }^{2}$, Neven Vidovic ${ }^{1}$, Jasen Vladislavic ${ }^{3}$ and Antonija Tadin ${ }^{4, *(D)}$ \\ 1 Study of Dental Medicine, School of Medicine, University of Split, 21000 Split, Croatia; \\ dariamad1995@gmail.com (D.M.); lgavic@mefst.hr (L.G.); neven.vidovic2@st.t-com.hr (N.V.) \\ 2 Department of Prosthodontics, Study of Dental Medicine, School of medicine, University of Split School \\ of Medicine, 21000 Split, Croatia; ikovacic@mefst.hr \\ 3 Department of Pulmonology, University Hospital Center Split, 21000 Split, Croatia; jvladislavic4@gmail.com \\ 4 Department of Restorative Dental Medicine and Endodontics, Study of Dental Medicine, School of Medicine, \\ University of Split, 21000 Split, Croatia \\ * Correspondence: atadin@mefst.hr or dr.antonija.tadin@gmail.com; Tel.: +385-98609191; Fax: +385-21557624
}

check for

updates

Citation: Madunic, D.; Gavic, L.; Kovacic, I.; Vidovic, N.; Vladislavic, J.; Tadin, A. Dentists' Opinions in Providing Oral Healthcare to Elderly People: A Questionnaire-Based Online Cross-Sectional Survey. Int. J. Environ. Res. Public Health 2021, 18, 3257. https://doi.org/10.3390/ ijerph18063257

Academic Editors: Paul Tchounwou

Received: 24 February 2021

Accepted: 19 March 2021

Published: 22 March 2021

Publisher's Note: MDPI stays neutra with regard to jurisdictional claims in published maps and institutional affiliations.

Copyright: (c) 2021 by the authors. Licensee MDPI, Basel, Switzerland. This article is an open access article distributed under the terms and conditions of the Creative Commons Attribution (CC BY) license (https:// creativecommons.org/licenses/by/ $4.0 /)$.

\begin{abstract}
This cross-sectional study aimed to assess the factors in dentists' opinions related to oral health and the treatment management of the elderly. An online questionnaire-based survey was conducted among the dentist population $(n=463)$. Respondents were divided depending on whether they attended the geriatric dentistry course during their education, and 15 questions on the Likert scale demonstrated the difference in their attitudes. The majority of respondents $(61.9 \%)$ agree that dental studies should pay more attention to acquiring sufficient knowledge and skills in the treatment of the elderly, and $56.2 \%$ would like to attend a course on that subject. Compared to those who participated in the geriatric dentistry course, those who did not consider providing oral healthcare to older people find it more difficult because of its complexity and practical obstacles (37.3\% vs. $54 \%, p \leq 0.001)$. From the results of this study, it can be concluded that there are differences in opinion about the provision of oral healthcare to the elderly between dentists who have and who have not attended a geriatric dentist course during their education. During the dentist's education, geriatric dentistry courses should have a significant role in providing knowledge for working with the elderly population.
\end{abstract}

Keywords: dentists; attitudes; elderly; geriatric dentistry

\section{Introduction}

In recent years, rapid growth in the number and percentage of older people in the total population is noted worldwide, more than at any other time in human history [1]. According to the World Health Organization definition, the elderly are considered people over 65 years of age. It is predicted that people aged 60 and over will make up half of the population by 2050 [2,3]. Although increasing the global community of older people is a medical achievement, it also poses significant healthcare system challenges. The ageing society brings many issues and challenges, including maintaining oral health $[4,5]$.

All organs are susceptible to ageing and the changes that accompany it, including the oral cavity. Good oral health can significantly contribute to the quality of daily life [6]. According to numerous studies conducted in different countries, the oral health of the elderly is flawed, and this results in a large number of lost teeth, dental caries, frequent periodontal diseases, decreased salivary gland function, and oral precancerous/cancerous conditions [6-9]. Oral health is primarily influenced by nutrition, genetics, and general health and hygiene, and with age, these factors only grow in influence. Poor oral health and dental pain can induce the reduction of eating ability, weight loss, speech impediments, problems with hydration, and decreased perceptions of personal appearance, which consequently lead to a loss of interest in social interactions [6,9-11]. Oral health is an essential 
element of the overall health and quality of life in an individual's life, which is why its continued promotion is necessary [12]. The demand for dental interventions among this population is much lower than is truly needed. The elderly can experience numerous barriers when going to the dentist, while dentists can experience difficulties in treating them. Barriers to dental healthcare for the elderly make access to the dentist's office complex, especially for those living in rural areas with low public transport. Furthermore, poor post-retirement socioeconomic status (high treatment costs), coupled with a lack of habit of going to the dentist, lack of oral health knowledge, and dental fear, can deter the elderly from visiting the dentist. Lack of empathy from dental staff and poor communication contribute to this [13-15]. Within the elderly population, functionally dependent people placed in nursing homes are at increased risk for developing an oral illness. The lack of interest in treating these individuals is often due to the facility's distance, lack of dentists time, no financial benefit, and poor education of the staff working in nursing homes [16].

Rare studies have shown slightly hostile or indifferent standpoints of dentists to treat the elderly and a low level of knowledge about the ageing process and the needs of the elderly $[17,18]$. Similar results were conducted among dental students [19,20]. Dentists' views on the oral health of the elderly do not depend on the amount of knowledge on the subject, but on the frequency of encountering and treating these patients. However, the contrary is often assumed. As most seniors use public health services, dentists working in these sectors have more experience and knowledge about treating them [21]. From their own experience, dentists generally believe that the health of the elderly is inadequate, and that more should be done to motivate them to take better care of their oral health. Furthermore, numerous difficulties prevent them from adequately treating the elderly, especially the disabled. Most often, these are a lack of time and insufficient financial compensation [15,22]. Important mechanisms for improving the oral health of the elderly are based on raising awareness of the importance of oral health, encouraging preventative programs at the national level within the framework of dental healthcare, and educating and training staff to provide services and care for the elderly [23,24].

In 2009, the European College of Gerodontology published the undergraduate curriculum guidelines in gerodontology to introduce this course in dental schools throughout Europe $[25,26]$. Geriatric dentistry has been established in the curricula of undergraduate dentistry courses in Croatia since 1994. All four Croatian dental schools have a particular geriatric dentistry education module integrated into the undergraduate curriculum during the fifth or sixth year of the program as an independent course, followed by the lectures in other courses. In three dental schools, it is mandatory, while in one, it is an elective/optional course. This course is taught by a multidisciplinary team from different departments (endodontics, restorative dentistry, prosthodontics, oral surgery, oral medicine, and periodontology) that provides curriculum content thought didactic lectures and seminars. Only one school has clinical components in a geriatric dentistry course. The topics underlying the geriatric dental program include a wide range of issues that can be classified as traditional, with the majority focusing on geriatric medical and oral problems, diagnosis and management and oral manifestations of systemic disease in the ageing, geriatric nutrition, oral mucosal diseases of older people, prosthodontics, and periodontal, endodontic, restorative, and surgical treatment of the older patient.

This study aimed to evaluate dentists' opinions about attitudes, knowledge, and barriers in providing oral health services to older people. The specific aim was to determine the difference between these viewpoints on deepening their undergraduate geriatric dental education. The null hypothesis was that there would be no differences in dentists' opinions, depending on whether they attended a geriatric dentistry course during their dental education. 


\section{Materials and Methods}

\subsection{Study Design and Ethical Approval}

The online, email-based, cross-sectional study was designed to assess dentists' opinions regarding their work with the elderly. It was conducted at the Department of Restorative Dental Medicine and Endodontics, Study of Dental Medicine, School of Medicine, the University of Split during March 2019. The study was approved by the Ethics Committee of the School of Medicine, the University of Split (No: 2181-198-03-04-19-0057), who also confirmed that the research was in full accordance with ethical principles, including the World Medical Association Declaration of Helsinki (version 2013). The study was performed following the Reporting of Observational Studies in Epidemiology (STROBE) guidelines. Information about the study was included in the email to the potential participants, stating that participation was voluntary, anonymous, and without compensation. Informed consent was considered to be obtained through the act of responding.

\subsection{Study Population}

The study was conducted among dentists who had at least one year of working experience at a dental office. Only dentists in active clinical work were included in the sample, and those living and working in Croatia. The exclusion criteria were participants aged $\geq 65$ years and those who had provided incomplete responses in the questionnaire.

The minimum required sample size $(n=358)$ was calculated from the total number of active members of the Croatian Chamber of Dental Medicine in $2019(n=5114)$ with a 95\% confidence interval, a $5 \%$ margin of error, and a population proportion of $50 \%$.

The online questionnaire designed in Google Forms was sent to 700 randomly generated dentists' email addresses. The total response rate was $463(66.1 \%)$. The majority of the participants were females $(68.3 \%)$. The mean age of all respondents was $39.7 \pm 10.7$. Furthermore, the mean age of respondents who attended geriatric dentistry courses during their undergraduate education was $33.6 \pm 6.6$, while, for those who did not, it was $45.7 \pm 9.9$.

\section{Measurement}

A self-administered questionnaire on the dentists' opinions in providing oral healthcare to the elderly was developed based on a relevant literature review [27].

The main questionnaire was arranged into three sections. The first section consisted of questions related to participant demographics and professional data (age, gender, year of graduation, academic degree, workplace, type of practice, number of working hours per day, number of patients per working day, and the proportion of elderly patients in the total number of patients). The second section consisted of six questions addressing the oral health opinions of elderly patients. The third section involved 15 items regarding respondents' views on knowledge, attitudes, and barriers in providing oral care to older people, employing a Likert scale. Dentists' opinions were rated on a five-category Likert-type scale $(1=$ totally disagree, $5=$ totally agree). For the sake of simplicity, results were divided into three groups: 0 - disagree (1 and 2), 1-neither agree nor disagree (3), 2-agree (4 and 5).

The questionnaire was initially designed in English and translated into Croatian by experts in the field [27]. After translation and back translation, to assure the quality of the data, the questionnaire was pilot tested on 25 dentists who were not included among the study participants. These participants determined the acceptability and clarity of the questions to confirm their face validity. The reliability of the opinion questionnaires was checked, and the value of Cronbach's alpha was 0.793.

Primary outcomes were dentists' opinions regarding knowledge, attitudes, and barriers to providing oral healthcare to the elderly. The attendance of geriatric dentistry courses during undergraduate education was considered an independent variable in the analysis, and the whole sample was divided into two groups according to that. The secondary outcome was respondents' views on knowledge, attitudes, and barriers in providing oral care to older people, depending on demographic and personal characteristics. 


\subsection{Statistical Analysis}

Data were analyzed by the Statistical Package for the Social Sciences version 25 (SPSS, IBM Corp, Armonk, New York, NY, USA). The participants were grouped depending on their education in the field of geriatric dentistry. Categorical variables were presented as whole numbers $(n)$ and percentages (\%), while means and standard deviations were used for quantitative variables. Statistical analyses were conducted using the Pearson's chi-square, Fisher's, and the Mann-Whitney U tests. Multiple linear regression analysis was used to determine the relationship of the dentists' opinions about providing oral healthcare to the elderly and their personal and professional data. The level of statistical significance was set at $p<0.05$.

\section{Results}

The respondents' personal and professional data are presented in Table 1. The total number of respondents who participated in this survey was 463 , while two-thirds (68.3\%) of the respondents were female. Half of the sample $(n=229,49.5 \%)$ had 10 to 15 patients per day, and $42.1 \%$ had $11-30 \%$ elderly ( $\geq 65$ years) patients in the total number of patients. The ratio between the respondents who attended geriatric dentistry courses during their education versus those who did not attend was $49.2 \%$ versus $50.7 \%$. More than half (56.2\%) of the respondents indicated that they would like to participate in a course on oral medicine related to oral health and oral care in the elderly. Depending on whether or not they had participated in geriatric dentistry courses during their education, and considering personal and professional data, a statistically significant difference was observed related to gender $(p \leq 0.001)$, age $(p \leq 0.001)$, year of graduation $(p \leq 0.001)$, number of working hours $(p \leq 0.001)$, qualification $(p=0.004)$, and workplace $(p=0.002)$.

Table 1. Personal and professional data of the respondents.

\begin{tabular}{|c|c|c|c|c|c|}
\hline \multicolumn{2}{|c|}{ Characteristic } & $\begin{array}{c}\text { Total } \\
(n=463)\end{array}$ & $\begin{array}{c}\text { NGC } \\
(n=235)\end{array}$ & $\begin{array}{c}\text { GC } \\
(n=228)\end{array}$ & $p$ \\
\hline \multirow{2}{*}{ Gender } & Male, $n(\%)$ & 147 (31.7) & $74(31.5)$ & $73(32.0)$ & \multirow{2}{*}{$\leq 0.001$ * } \\
\hline & Female, $n(\%)$ & $316(68.3)$ & $161(68.5)$ & $155(68.0)$ & \\
\hline \multicolumn{2}{|c|}{ Mean age (SD) } & $39.7(10.7)$ & $45.7(9.9)$ & $33.6(7.5)$ & $\leq 0.0011^{\#}$ \\
\hline \multirow{3}{*}{$\begin{array}{l}\text { Academic } \\
\text { Degree }\end{array}$} & Dentist, $n(\%)$ & $372(80.3)$ & $180(76.5)$ & $192(84.2)$ & \multirow{3}{*}{$0.004^{*}$} \\
\hline & Master of Science, $n(\%)$ & $40(8.7)$ & $18(7.7)$ & $22(9.6)$ & \\
\hline & Doctor of Science, $n(\%)$ & $51(11.0)$ & $37(15.7)$ & $14(6.1)$ & \\
\hline \multirow{4}{*}{ Workplace (region) } & Northern Croatia, $n(\%)$ & $172(37.1)$ & $100(42.6)$ & $72(31.6)$ & \multirow{4}{*}{$0.002 *$} \\
\hline & Eastern Croatia, $n(\%)$ & $58(12.5)$ & $22(9.4)$ & $36(15.8)$ & \\
\hline & Southern Croatia, $n(\%)$ & $187(40.4)$ & $83(35.3)$ & $104(45.6)$ & \\
\hline & Western Croatia, $n(\%)$ & $46(9.9)$ & $30(12.8)$ & $16(7.0)$ & \\
\hline \multirow[t]{2}{*}{ Type of practice (specialty) } & $\begin{array}{c}\text { General dental } \\
\text { practitioner, } n(\%)\end{array}$ & $402(86.8)$ & $195(83.0)$ & $206(90.4)$ & \multirow[t]{2}{*}{$0.014^{\#}$} \\
\hline & Specialist, $n(\%)$ & $61(13.2)$ & $40(17.0)$ & $22(9.6)$ & \\
\hline \multirow{5}{*}{ Year of dental graduation } & 1979 or earlier, $n(\%)$ & $11(2.4)$ & $10(4.3)$ & $1(0.4)$ & \multirow{5}{*}{$\leq 0.001 * *$} \\
\hline & $1980-1989, n(\%)$ & $57(12.3)$ & $53(22.6)$ & $4(1.8)$ & \\
\hline & $1990-1999, n(\%)$ & $101(21.8)$ & $91(38.7)$ & $10(4.4)$ & \\
\hline & 2000-2010, $n(\%)$ & $161(34.8)$ & $60(25.5)$ & $101(44.3)$ & \\
\hline & 2010 or later, $n(\%)$ & $133(28.7)$ & $21(8.9)$ & $112(49.1)$ & \\
\hline
\end{tabular}


Table 1. Cont.

\begin{tabular}{|c|c|c|c|c|c|}
\hline Characteristi & & $\begin{array}{c}\text { Total } \\
(n=463)\end{array}$ & $\begin{array}{c}\text { NGC } \\
(n=235)\end{array}$ & $\begin{array}{c}\text { GC } \\
(n=228)\end{array}$ & $p$ \\
\hline \multirow{2}{*}{ Number of working hours per day } & $\leq 8, n(\%)$ & $340(73.4)$ & $190(80.8)$ & $150(65.7)$ & \multirow{2}{*}{$\leq 0.001 *$} \\
\hline & $>8, n(\%)$ & $123(26.6)$ & $45(19.1)$ & $78(34.2)$ & \\
\hline \multirow{3}{*}{ Number of patients per working day } & $<10, n(\%)$ & $128(27.6)$ & $68(28.9)$ & $60(26.3)$ & \multirow{3}{*}{$0.267 *$} \\
\hline & $10-15, n(\%)$ & $229(49.5)$ & $121(51.5)$ & $108(47.4)$ & \\
\hline & $>15, n(\%)$ & $106(22.9)$ & $46(19.6)$ & $60(26.3)$ & \\
\hline \multirow{3}{*}{$\begin{array}{l}\text { The proportion of elderly patients } \\
(\geq 65 \text { years) in the total number } \\
\text { of patients }\end{array}$} & $\leq 10 \%, n(\%)$ & $94(20.3)$ & $52(22.1)$ & $42(18.4)$ & \multirow{3}{*}{$0.321 *$} \\
\hline & $11-30 \%, n(\%)$ & $195(42.1)$ & $103(43.8)$ & $92(40.4)$ & \\
\hline & $>31 \%, n(\%)$ & $174(37.6)$ & $80(34.0)$ & $94(41.2)$ & \\
\hline \multirow{2}{*}{$\begin{array}{l}\text { Desire to attend a course/congress on } \\
\text { the subject of geriatric dentistry }\end{array}$} & No, $n(\%)$ & $203(43.8)$ & $111(47.2)$ & $92(40.4)$ & \multirow{2}{*}{0.081 * } \\
\hline & Yes, $n(\%)$ & $260(56.2)$ & $124(52.8)$ & $136(59.6)$ & \\
\hline
\end{tabular}

Table 2 shows the opinions of the respondents related to the oral health of the elderly, depending on whether they attended a geriatric dentistry course or not. Most of the respondents believed that older adults have poor oral health and do not regularly attend dental examinations ( $54.2 \%$ and $66.9 \%$, respectively). Furthermore, $60 \%$ of dentists $(n=278)$ did not think that the elderly should come to regular check-ups more often than the rest of the population. Over $80 \%(n=386)$ considered poor oral health a risk factor for general health, and $70 \%(n=325)$ believed that tooth loss is not necessarily an ageing consequence.

Table 2. Respondents' opinion on the oral health of the elderly $(n=463)$.

\begin{tabular}{|c|c|c|c|c|}
\hline \multicolumn{2}{|c|}{ Opinion } & $\begin{array}{c}\text { NGC } \\
(n=235)\end{array}$ & $\begin{array}{c}\text { GC } \\
(n=228)\end{array}$ & $p$ \\
\hline \multirow{3}{*}{$\begin{array}{l}\text { Oral health of the elderly } \\
\text { in Croatia }\end{array}$} & Bad & $132(56.1)$ & $119(52.2)$ & \multirow{3}{*}{0.020} \\
\hline & Sufficient & $85(36.2)$ & $79(34.6)$ & \\
\hline & Good & $18(7.7)$ & $30(13.2)$ & \\
\hline \multirow{3}{*}{$\begin{array}{l}\text { Older people regularly come to } \\
\text { dental examinations }\end{array}$} & (Totally/partially) disagree & $179(76.2)$ & $131(57.5)$ & \multirow{3}{*}{0.053} \\
\hline & Neither agree nor disagree & $16(6.8)$ & $21(9.2)$ & \\
\hline & (Totally/partially) agree & $40(17.0)$ & $76(33.3)$ & \\
\hline \multirow{3}{*}{$\begin{array}{l}\text { Older people should come to the } \\
\text { dental exam more often than } \\
\text { younger people }\end{array}$} & (Totally/partially) disagree & $142(60.4)$ & $136(59.6)$ & \multirow{3}{*}{0.980} \\
\hline & Neither agree nor disagree & $74(31.5)$ & $75(32.9)$ & \\
\hline & (Totally/partially) agree & $19(8.1)$ & $17(7.5)$ & \\
\hline \multirow{3}{*}{$\begin{array}{l}\text { Providing dental care to older } \\
\text { people is more demanding than } \\
\text { it is to younger patients }\end{array}$} & (Totally/partially) disagree & $138(58.7)$ & $109(47.8)$ & \multirow{3}{*}{0.002} \\
\hline & Neither agree nor disagree & $1(0.4)$ & $13(5.7)$ & \\
\hline & (Totally/partially) agree & $96(40.9)$ & $106(46.5)$ & \\
\hline \multirow{3}{*}{$\begin{array}{l}\text { In the elderly, poor oral health is } \\
\text { considered a risk factor for } \\
\text { general health problems }\end{array}$} & (Totally/partially) disagree & $9(3.8)$ & $9(3.9)$ & \multirow{3}{*}{0.736} \\
\hline & Neither agree nor disagree & $32(13.6)$ & $27(11.8)$ & \\
\hline & (Totally/partially) agree & $194(82.6)$ & $192(84.2)$ & \\
\hline \multirow{3}{*}{$\begin{array}{l}\text { Tooth loss in the elderly is an } \\
\text { inevitable consequence of aging }\end{array}$} & (Totally/partially) disagree & $149(63.4)$ & $176(77.2)$ & \multirow{3}{*}{$\leq 0.001$} \\
\hline & Neither agree nor disagree & $43(18.3)$ & $29(12.7)$ & \\
\hline & (Totally/partially) agree & $43(18.3)$ & $23(10.1)$ & \\
\hline
\end{tabular}

Data are shown as a number and percentage. Statistical significance was tested by the chi-squared test, $\mathrm{df}=2$. Statistical significance was set to $p<0.05$. Abbreviations: NGC—did not attend a geriatric dentistry course; GC—attended a geriatric dentistry course. 
Table 3 presents the respondents' opinions about attitudes, knowledge, and barriers in providing oral health services to older people, depending on whether they attended a geriatric dentistry course during their studies. Those who did not participate in a course during their study felt that more attention should be paid to sufficient knowledge of treating ageing people in dental schools instead of those who have attended a course (166 vs. 121, $p \leq 0.001)$. Also, more of those participants stated that work with the elderly is difficult because of its complexity and practical obstacles (127 vs. $85, p \leq 0.001$ ); moreover, they considered insufficient healthcare reimbursement for dental care of the elderly as a barrier for a professional commitment compared to those who participated in a course ( $99 \mathrm{vs} .72$, $p \leq 0.0001)$. Likewise, those who had participated in a course considered themselves able to provide oral healthcare to cognitively impaired older adults more than those who have not attended one (171 vs. $153, p=0.028)$.

Table 3. Respondents' opinions on knowledge, attitudes, and barriers in providing oral care to older people depending on whether or not they attended a geriatric dentistry course during their education.

\begin{tabular}{|c|c|c|c|c|}
\hline Question & & $\begin{array}{c}\text { NGC } \\
(n=235)\end{array}$ & $\begin{array}{c}\mathrm{GC} \\
(n=228)\end{array}$ & $p$ \\
\hline \multirow{3}{*}{$\begin{array}{l}\text { Q1-Physical, psychological, and social aspects } \\
\text { may influence decision-making considering oral } \\
\text { healthcare for older people }\end{array}$} & (Totally/partially) agree & $162(68.9)$ & $156(68.4)$ & \multirow{3}{*}{$0.020 *$} \\
\hline & Neither agree nor disagree & $34(14.5)$ & $50(29.1)$ & \\
\hline & (Totally/partially) disagree & $39(16.6)$ & $22(9.6)$ & \\
\hline \multirow{3}{*}{$\begin{array}{l}\text { Q2-I have sufficient knowledge of the (adverse) } \\
\text { effects of medicines commonly used by } \\
\text { older people }\end{array}$} & (Totally/partially) agree & $97(41.3)$ & $116(50.9)$ & \multirow{3}{*}{$0.053 *$} \\
\hline & Neither agree nor disagree & $74(31.5)$ & $69(30.3)$ & \\
\hline & (Totally/partially) disagree & $64(27.2)$ & $43(18.9)$ & \\
\hline \multirow{3}{*}{$\begin{array}{l}\text { Q3-I am able to provide oral healthcare to } \\
\text { cognitively impaired seniors }\end{array}$} & (Totally/partially) agree & $149(63.4)$ & $139(61.0)$ & \multirow{3}{*}{$0.463 *$} \\
\hline & Neither agree nor disagree & $69(29.4)$ & $77(33.8)$ & \\
\hline & (Totally/partially) disagree & $17(7.2)$ & $12(5.3)$ & \\
\hline \multirow{3}{*}{$\begin{array}{l}\text { Q4-Dental medicine studies should pay more } \\
\text { attention to the acquisition of sufficient knowledge } \\
\text { and skills in the treatment of older people }\end{array}$} & (Totally/partially) agree & $166(70.6)$ & $121(53.0)$ & \multirow{3}{*}{$\leq 0.001 *$} \\
\hline & Neither agree nor disagree & $60(25.5)$ & $91(39.9)$ & \\
\hline & (Totally/partially) disagree & $9(3.83)$ & $16(7.0)$ & \\
\hline \multirow{3}{*}{$\begin{array}{l}\text { Q5-Oral hygiene is a prerequisite for preventing } \\
\text { oral health problems in older people }\end{array}$} & (Totally/partially) agree & $223(94.8)$ & $211(92.5)$ & \multirow{3}{*}{$0.542 * *$} \\
\hline & Neither agree nor disagree & $10(4.3)$ & $15(6.6)$ & \\
\hline & (Totally/partially) disagree & $2(0.9)$ & $2(0.9)$ & \\
\hline \multirow{3}{*}{$\begin{array}{l}\text { Q6-Each dentist is responsible for providing } \\
\text { proper oral healthcare to elderly people who are } \\
\text { unable to leave their home, but who have } \\
\text { previously regularly come to their practice (with } \\
\text { the precondition that they are their patients) }\end{array}$} & (Totally/partially) agree & $117(49.8)$ & $119(52.2)$ & \multirow{3}{*}{0.051 * } \\
\hline & Neither agree nor disagree & $70(29.8)$ & $81(35.5)$ & \\
\hline & (Totally/partially) disagree & $48(20.4)$ & $28(12.3)$ & \\
\hline \multirow{3}{*}{$\begin{array}{c}\text { Q7-I am prepared to do a regular dental } \\
\text { examination to an elderly and infirm person via a } \\
\text { home visit }\end{array}$} & (Totally/partially) agree & $162(68.9)$ & $174(76.3)$ & \multirow{3}{*}{$0.182 *$} \\
\hline & Neither agree nor disagree & $54(23.0)$ & $42(18.4)$ & \\
\hline & (Totally/partially) disagree & $19(8.1)$ & $12(5.3)$ & \\
\hline \multirow{3}{*}{$\begin{array}{l}\text { Q8-I have repeatedly experienced that at some } \\
\text { point older, disabled people stopped coming for } \\
\text { regular check-ups (appointments) }\end{array}$} & (Totally/partially) agree & $142(60.4)$ & $139(60.9)$ & \multirow{3}{*}{$0.007^{*}$} \\
\hline & Neither agree nor disagree & $48(20.4)$ & $66(28.9)$ & \\
\hline & (Totally/partially) disagree & $45(19.1)$ & $23(10.2)$ & \\
\hline
\end{tabular}


Table 3. Cont.

\begin{tabular}{|c|c|c|c|c|}
\hline Question & & $\begin{array}{c}\text { NGC } \\
(n=235)\end{array}$ & $\begin{array}{c}\mathrm{GC} \\
(n=228)\end{array}$ & $p$ \\
\hline \multirow{3}{*}{$\begin{array}{l}\text { Q9-From the dentist's point of view, treating the } \\
\text { vulnerable elderly is not too demanding }\end{array}$} & (Totally/partially) agree & $43(18.3)$ & 44 (19.3) & \multirow{3}{*}{$0.873 *$} \\
\hline & Neither agree nor disagree & $75(31.9)$ & $76(33.3)$ & \\
\hline & (Totally/partially) disagree & $117(49.8)$ & $108(47.4)$ & \\
\hline \multirow{3}{*}{$\begin{array}{l}\text { Q10_Possibilities for referrals of elderly people } \\
\text { with complex oral health problems to fellow } \\
\text { specialists are limited }\end{array}$} & (Totally/partially) agree & $123(52.3)$ & $136(59.6)$ & \multirow{3}{*}{$0.127 *$} \\
\hline & Neither agree nor disagree & $52(22.1)$ & $51(22.4)$ & \\
\hline & (Totally/partially) disagree & $60(25.5)$ & $41(18.0)$ & \\
\hline \multirow{3}{*}{$\begin{array}{l}\text { Q11-Providing oral healthcare to older people is } \\
\text { difficult because of its complexity and } \\
\text { practical obstacles }\end{array}$} & (Totally/partially) agree & $127(54.0)$ & $85(37.3)$ & \multirow{3}{*}{$\leq 0.001 *$} \\
\hline & Neither agree nor disagree & $56(23.8)$ & $82(36.0)$ & \\
\hline & (Totally/partially) disagree & $52(22.1)$ & $61(26.8)$ & \\
\hline \multirow{3}{*}{$\begin{array}{l}\text { Q12-The reimbursement for providing oral health } \\
\text { care to vulnerable older people is insufficient }\end{array}$} & (Totally/partially) agree & $148(63.0)$ & $121(53.1)$ & \multirow{3}{*}{0.065 * } \\
\hline & Neither agree nor disagree & $72(30.6)$ & $83(36.4)$ & \\
\hline & (Totally/partially) disagree & $15(6.4)$ & $24(10.5)$ & \\
\hline \multirow{3}{*}{$\begin{array}{l}\text { Q13-The institution (dental office) where I } \\
\text { practice is easily accessible to the elderly (no } \\
\text { major obstacles) }\end{array}$} & (Totally/partially) agree & $153(65.1)$ & $171(75.0)$ & \multirow{3}{*}{$0.028 *$} \\
\hline & Neither agree nor disagree & $24(10.2)$ & $23(10.1)$ & \\
\hline & (Totally/partially) disagree & $58(24.7)$ & $34(14.9)$ & \\
\hline \multirow{3}{*}{$\begin{array}{l}\text { Q14-Usually, the provision of oral healthcare to } \\
\text { the elderly involves various technical limitations }\end{array}$} & (Totally/partially) agree & $121(51.5)$ & $103(45.2)$ & \multirow{3}{*}{$0.027^{*}$} \\
\hline & Neither agree nor disagree & $55(23.4)$ & $79(34.6)$ & \\
\hline & (Totally/partially) disagree & $59(25.1)$ & $46(20.2)$ & \\
\hline \multirow{3}{*}{$\begin{array}{l}\text { Q15-I find that insufficient reimbursement for the } \\
\text { provision of oral healthcare to older people is a } \\
\text { barrier to the professional commitment to this } \\
\text { particular group of patients }\end{array}$} & (Totally/partially) agree & $99(42.1)$ & $72(31.6)$ & \multirow{3}{*}{$\leq 0.001$ * } \\
\hline & Neither agree nor disagree & $55(23.4)$ & $96(42.1)$ & \\
\hline & (Totally/partially) disagree & $81(34.5)$ & $60(26.3)$ & \\
\hline
\end{tabular}

Data are shown as a number and percentage. Statistical significance was tested by the * chi-square or ${ }^{* *}$ Fisher's tests. Statistical significance was set to $p<0.05$. Abbreviations: NGC—-did not attend a geriatric dentistry course; GC—attended a geriatric dentistry course.

The results shown in Table 4 indicate that the attendance of geriatric dentistry courses during undergraduate education is a statistically significant predictor of respondents knowledge regarding (adverse) effects of medicines commonly used by older people $(\beta=0.265, \mathrm{SE}=0.91, p=0.004)$, and willingness to do a regular dental examination to an elderly and infirm person via a home visit $(\beta=0.170, \mathrm{SE}=0.070, p=0.015)$. Furthermore, the attendance of geriatric dentistry courses during undergraduate education is negatively correlated with the opinion that providing oral healthcare to older people is difficult because of its complexity and practical obstacles $(\beta=-0.294, \mathrm{SE}=0.94, p=0.002)$, and that insufficient reimbursement for the provision of oral healthcare to older people is a barrier to the professional $(\beta=-0.208, \mathrm{SE}=0.94, p=0.027)$. A detailed analysis of the regression models is shown in Table 4. 


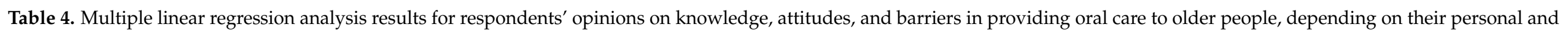
professional data.

\begin{tabular}{|c|c|c|c|c|c|c|c|}
\hline \multirow[b]{2}{*}{ Question } & & \multicolumn{6}{|c|}{ Predictors } \\
\hline & & Gender & Age & $\begin{array}{c}\text { Year of } \\
\text { Graduation }\end{array}$ & Specialty & $\begin{array}{l}\text { Number of Elderly } \\
\text { Patients in Care }\end{array}$ & $\begin{array}{l}\text { Attended Geriatric } \\
\text { Dentistry Course }\end{array}$ \\
\hline \multirow{3}{*}{$\begin{array}{l}\text { Q1-Physical, psychological, and social aspects may influence } \\
\text { decision-making considering oral healthcare for older people }\end{array}$} & $\beta$ & -0.081 & -0.002 & 0.028 & 0.060 & 0.083 & 0.039 \\
\hline & $\mathrm{t}$ & 0.071 & 0.051 & 0.062 & 0.025 & 0.037 & 0.083 \\
\hline & $p$ & 0.253 & 0.975 & 0.650 & 0.016 & 0.026 & 0.645 \\
\hline \multirow{2}{*}{$\begin{array}{l}\text { Q2-I have sufficient knowledge of the (adverse) effects of } \\
\text { medicines commonly used by older people }\end{array}$} & $\beta$ & -0.121 & 0.030 & -0.052 & 0.027 & 0.060 & 0.265 \\
\hline & $p$ & 0.118 & 0.586 & 0.436 & 0.321 & 0.135 & 0.004 \\
\hline \multirow{3}{*}{$\begin{array}{l}\text { Q3-I am able to provide oral healthcare to cognitively } \\
\text { impaired seniors }\end{array}$} & $\beta$ & -0.078 & 0.101 & 0.099 & 0.041 & 0.085 & -0.005 \\
\hline & $t$ & 0.060 & 0.043 & 0.052 & 0.021 & 0.031 & 0.070 \\
\hline & $p$ & 0.193 & 0.018 & 0.057 & 0.048 & 0.007 & 0.939 \\
\hline \multirow{2}{*}{$\begin{array}{l}\text { Q4-Dental medicine studies should pay more attention to } \\
\text { the acquisition of sufficient knowledge and skills in the } \\
\text { treatment of older people }\end{array}$} & $\beta$ & 0.049 & 0.108 & 0.113 & 0.012 & 0.081 & -0.209 \\
\hline & $\mathrm{t}$ & 0.058 & 0.042 & 0.050 & 0.020 & 0.030 & 0.068 \\
\hline \multirow{3}{*}{$\begin{array}{l}\text { Q5-Oral hygiene is a prerequisite for preventing oral health } \\
\text { problems in older people }\end{array}$} & $\beta$ & -0.035 & 0.011 & -0.010 & 0.001 & 0.006 & 0.005 \\
\hline & $t$ & 0.029 & 0.021 & 0.025 & 0.010 & 0.015 & 0.034 \\
\hline & $p$ & 0.233 & 0.595 & 0.696 & 0.939 & 0.679 & 0.886 \\
\hline \multirow{3}{*}{$\begin{array}{l}\text { Q6-Each dentist is responsible for providing proper oral } \\
\text { healthcare to elderly people who are unable to leave their } \\
\text { home, but who have previously regularly come to their } \\
\text { practice (with the precondition that they are their patients) }\end{array}$} & $\beta$ & -0.036 & 0.102 & 0.124 & 0.100 & 0.131 & 0.101 \\
\hline & $\mathrm{t}$ & 0.072 & 0.052 & 0.063 & 0.025 & 0.038 & 0.085 \\
\hline & $p$ & 0.615 & 0.049 & 0.049 & $\leq 0.001$ & $\leq 0.001$ & 0.239 \\
\hline \multirow{3}{*}{$\begin{array}{l}\text { Q7-I am prepared to do a regular dental examination to an } \\
\text { elderly and infirm person via a home visit }\end{array}$} & $\beta$ & -0.070 & 0.067 & 0.022 & 0.036 & -0.012 & 0.170 \\
\hline & $\mathrm{t}$ & 0.059 & 0.043 & 0.052 & 0.021 & 0.031 & 0.070 \\
\hline & $p$ & 0.238 & 0.114 & 0.667 & 0.084 & 0.708 & 0.015 \\
\hline
\end{tabular}


Table 4. Cont.

\begin{tabular}{|c|c|c|c|c|c|c|c|}
\hline \multirow[b]{2}{*}{ Question } & & \multicolumn{6}{|c|}{ Predictors } \\
\hline & & Gender & Age & $\begin{array}{c}\text { Year of } \\
\text { Graduation }\end{array}$ & Specialty & $\begin{array}{l}\text { Number of Elderly } \\
\text { Patients in Care }\end{array}$ & $\begin{array}{l}\text { Attended Geriatric } \\
\text { Dentistry Course }\end{array}$ \\
\hline \multirow{3}{*}{$\begin{array}{l}\text { Q8-I have repeatedly experienced that at some point older, } \\
\text { disabled people stopped coming for regular check-ups } \\
\text { (appointments) }\end{array}$} & $\beta$ & 0.020 & -0.010 & -0.001 & -0.065 & 0.153 & 0.026 \\
\hline & $\mathrm{t}$ & 0.071 & 0.051 & 0.062 & 0.025 & 0.037 & 0.084 \\
\hline & $p$ & 0.776 & 0.843 & 0.992 & 0.009 & $\leq 0.001$ & 0.753 \\
\hline \multirow{2}{*}{$\begin{array}{l}\text { Q9-From the dentist's point of view, treating the vulnerable } \\
\text { elderly is not too demanding }\end{array}$} & $\beta$ & -0.006 & 0.066 & -0.007 & 0.017 & 0.056 & 0.126 \\
\hline & $p$ & 0.939 & 0.228 & 0.913 & 0.531 & 0.164 & 0.164 \\
\hline \multirow{3}{*}{$\begin{array}{l}\text { Q10-Possibilities for referrals of elderly people with complex } \\
\text { oral health problems to fellow specialists are limited }\end{array}$} & $\beta$ & 0.265 & 0.091 & 0.141 & -0.027 & -0.020 & 0.102 \\
\hline & $\mathrm{t}$ & 0.079 & 0.057 & 0.069 & 0.028 & 0.042 & 0.093 \\
\hline & $p$ & $\leq 0.001$ & 0.107 & 0.041 & 0.326 & 0.634 & 0.275 \\
\hline \multirow{2}{*}{$\begin{array}{l}\text { Q11-Providing oral healthcare to older people is difficult } \\
\text { because of its complexity and practical obstacles }\end{array}$} & $\beta$ & 0.097 & -0.010 & 0.082 & 0.078 & -0.051 & -0.294 \\
\hline & $\mathrm{t}$ & 0.079 & 0.057 & 0.069 & 0.028 & 0.042 & 0.094 \\
\hline \multirow{3}{*}{$\begin{array}{l}\text { Q12-The reimbursement for providing oral healthcare to } \\
\text { vulnerable older people is insufficient }\end{array}$} & $\beta$ & 0.054 & 0.068 & 0.057 & 0.063 & 0.003 & -0.098 \\
\hline & $\mathrm{t}$ & 0.064 & 0.046 & 0.056 & 0.022 & 0.034 & 0.076 \\
\hline & $p$ & 0.400 & 0.139 & 0.306 & 0.005 & 0.925 & 0.195 \\
\hline \multirow{3}{*}{$\begin{array}{l}\text { Q13-The institution (dental office) where I practice is easily } \\
\text { accessible to the elderly (no major obstacles) }\end{array}$} & $\beta$ & -0.082 & -0.045 & 0.010 & -0.116 & -0.007 & 0.090 \\
\hline & $\mathrm{t}$ & 0.079 & 0.056 & 0.069 & 0.028 & 0.041 & 0.093 \\
\hline & $p$ & 0.296 & 0.430 & 0.888 & $\leq 0.001$ & 0.871 & 0.334 \\
\hline \multirow{3}{*}{$\begin{array}{l}\text { Q14-Usually, the provision of oral healthcare to the elderly } \\
\text { involves various technical limitations }\end{array}$} & $\beta$ & 0.195 & 0.157 & 0.242 & 0.133 & -0.003 & -0.058 \\
\hline & $\mathrm{t}$ & 0.077 & 0.055 & 0.067 & 0.027 & 0.040 & 0.091 \\
\hline & $p$ & 0.012 & 0.005 & $\leq 0.001$ & $\leq 0.001$ & 0.947 & 0.522 \\
\hline \multirow{3}{*}{$\begin{array}{l}\text { Q15-I find that insufficient reimbursement for the provision } \\
\text { of oral healthcare to older people is a barrier to the } \\
\text { professional commitment to this particular group of patients }\end{array}$} & $\beta$ & 0.115 & -0.003 & 0.150 & 0.104 & 0.126 & -0.208 \\
\hline & $\mathrm{t}$ & 0.079 & 0.057 & 0.069 & 0.028 & 0.042 & 0.094 \\
\hline & $p$ & 0.149 & 0.959 & 0.030 & $\leq 0.001$ & 0.003 & 0.027 \\
\hline
\end{tabular}




\section{Discussion}

The aim of this study was to assess dentists' attitudes, experience, and practice towards oral healthcare of the elderly. Four hundred and sixty-three dentists answered surveys, which is $9.1 \%$ of the total number of dentists in Croatia. A similar number of respondents attended $(n=228)$ and did not attend $(n=235)$ geriatric dentistry courses during their education. The null hypothesis was not confirmed, since there are verified differences in attitudes, knowledge, and practice among these two groups. Respondents who have attended the course consider that providing dental care to the elderly was more demanding than to the younger patients $(p=0.002)$, and that tooth loss in the elderly is not an inevitable consequence of ageing $(p \leq 0.001)$. Poor oral health in the elderly is primarily seen with high tooth loss levels, dental caries, the prevalence of periodontal disease, xerostomia, precancerous lesions, and oral cancer. The basis for prevention relates to the detection of these diseases and conditions of the oral cavity at the earliest possible stages, which requires regular sessions with the patient. A dentist should work to discard the premise that any oral disease is an inevitable consequence of ageing [10].

The results also showed that $50.9 \%$ the geriatric dentistry course participants have sufficient knowledge about the harmful effects of medicines used by the elderly. Overall, most of the respondents $(61.9 \%)$ believed that more attention should be given to geriatric patients. The same result was obtained by a Dutch study conducted among a population of dentists [27].

More than half (59.6\%) respondents who attended a geriatric dentistry course considered that the possibility for a referral of older people with complicated oral health problems to a specialist is limited. While three quarters $(75 \%)$ of thembelieve that their offices are easily attainable to the elderly. Furthermore, only $26.8 \%$ find that providing oral healthcare to older people is not so difficult due to its complexity and practical obstacles, and only $10.5 \%$ consider how compensation for delivering oral healthcare to vulnerable older people sufficient. About $40 \%$ of the respondents believe that insufficient reimbursement for providing oral healthcare to the elderly hinders professional commitment. The same was confirmed in two studies conducted in the Netherlands in 2016 and 2017 [27,28]. Dentists who have a higher proportion of elderly people in the total number of patients believed that physical, psychological, and social aspects may influence decision-making considering oral healthcare for older people $(p=0.026)$, and can provide oral healthcare to cognitively impaired people $(p=0.007)$. They also think that more attention is needed to acquire additional knowledge in geriatric dentistry during studies $(p=0.008)$.

Furthermore, Dutch colleagues who had a higher number of older adults among their patients proved to be more capable of treating this population [27]. An American survey from 2012 emphasizes the importance of clinical work with medically disabled elderly adults during college [29]. Unlike the Dutch study, where many dentists stated that they did not know the adverse effects of medicines used by the elderly, we did not find any difference in the distribution of responses depending on the respondents' age or graduation year [28].

A minimal difference in attitudes was observed among respondents depending on agerelated questions of adequate education during studying $(p=0.010)$. Moreira et al. [21], in their research, found no difference in knowledge on ageing and aged people among dentists depending on the dentists' age. The same was confirmed for researchers from Brazil [30]. In this study, a minimal difference was also observed in gender-based attitudes. This premise has been confirmed in numerous similar studies [17,31]. Developing optimistic opinions towards the elderly can be vital to establish positive professional characteristics [32]. In this study, dentists with a higher proportion of the elderly in the total number of patients showed the most favorable opinions. It has already been demonstrated earlier that positive beliefs are influenced by personal experience and cultural and social values. While studying, the experience of working with professors who show empathy for the elderly influences the formation of student attitudes toward this particularly vulnerable part of the population [17,33,34]. Nochajski et al. [32] noticed a change in dental students' attitudes 
concerning older people after meetings with this population in the clinic sessions. It showed that contacts in the clinic were associated with more positive attitudes. On the contrary, a study conducted in Belgium demonstrated that interactions between institutionalized older people and dental students have no influence on recently graduated dentists' attitudes towards the institutionalized elderly [17].

This study has a few limitations. Since this was an observational, cross-sectional survey, participation was based on availability and willingness. Furthermore, dentists who chose to participate in the survey may be more interested or concerned with the elderly than those who did not participate.

\section{Conclusions}

In this study, dentists who took a geriatric dentistry course during their studies showed more positive attitudes towards working with elderly adults. Students' contact with older patients appears to be a key element in developing a positive approach to treating individuals in this rapidly growing segment of society. Therefore, it would be advisable and desirable to introduce a compulsory subject of geriatric dentistry at every dental school so that future doctors can acquire the knowledge and skills necessary to work with disabled and cognitively handicapped older people. Professors should pay more attention to this sensitive topic, as they are mainly responsible for educating students and developing their positive attitudes in the treatment of older people. The critical solution is to promote ongoing education and training based on clinical leadership.

Author Contributions: Each author has met the authorship requirements. A.T., L.G. and I.K. contributed substantially to the concept and design of the study. D.M., N.V. and J.V. significantly contributed to the acquisition of data. A.T. and L.G. have analyzed and interpreted the data. D.M., L.G., I.K., N.V., J.V. and A.T. performed the literature search and wrote the manuscript. All authors have revised the manuscript critically for important intellectual content, and all authors have read and agreed to the published version of the manuscript.

Funding: This research received no external funding.

Institutional Review Board Statement: The study was conducted according to the guidelines of the Declaration of Helsinki, and approved by the Ethics Committee of School of the Medicine, the University of Split (No: 2181-198-03-04-19-0057).

Informed Consent Statement: Written informed consent was obtained from all participants.

Data Availability Statement: The data that support the findings of this study are available from the corresponding author upon reasonable request.

Acknowledgments: The authors would like to thank all the dentists who responded and completed the questionnaire for collaborating in this study.

Conflicts of Interest: The authors declare no conflict of interest related to this study.

\section{References}

1. Ogura, S.; Jakovljevic, M.M. Editorial: Global Population Aging-Health Care, Social and Economic Consequences. Front. Public Health 2018, 6, 335. [CrossRef]

2. World Health Organization. Number of People over 60 Years set to Double by 2050; major societal changes required. Saudi Med. J. 2015, 36, 11.

3. World Health Organization: National Institute on Aging NIoHUS. Global Health and Aging; WHO: Geneva, Switzerland, 2011; pp. 2-4.

4. Branca, S.; Bennati, E.; Ferlito, L.; Spallina, G.; Cardillo, E.; Malaguarnera, M.; Motta, M. The health-care in the extreme longevity. Arch. Gerontol. Geriatr. 2009, 49, 32-34. [CrossRef]

5. Niessen, L.C.; Fedele, D.J. Aging successfully: Oral health for the prime of life. Compend. Contin. Educ. Dent. $2002,23,4-11$.

6. Gil-Montoya, J.A.; de Mello, A.L.; Barrios, R.; Gonzalez-Moles, M.A.; Bravo, M. Oral health in the elderly patient, and its impact on general well-being: A non-systematic review. Clin. Interv. Aging 2015, 10, 461-467. [CrossRef] [PubMed]

7. Hoeksema, A.R.; Peters, L.L.; Raghoebar, G.M.; Meijer, H.; Vissink, A.; Visser, A. Health and quali-ty of life differ between community living older people with and without remaining teeth who recently received formal home care: A cross sectional study. Clin. Oral Investig. 2018, 22, 2615-2622. [CrossRef] [PubMed] 
8. Wong, F.; Ng, Y.; Leung, W.K. Oral Health and Its Associated Factors among Older Institutionalized Resi-dents-A Systematic Review. Int. J. Environ. Res. Public Health 2019, 16, 4132. [CrossRef] [PubMed]

9. Petersen, P.E.; Ogawa, H. Promoting Oral Health and Quality of Life of Older People-The Need for Public Health Action. Oral Health Prev. Dent. 2018, 16, 113-124.

10. Razak, P.A.; Richard, K.M.J.; Thankachan, R.P.; Hafiz, K.A.A.; Kumar, K.N.; Sameer, K.M. Geriatric Oral Health: A Review Article. J. Int. Oral Health 2015, 6, 110.

11. van der Putten, G.J.; de Baat, C.; de Visschere, L.; Schols, J. Poor oral health, a potential new geriatric syn-drome. Gerodontology 2014, 31, 17-24. [CrossRef]

12. Hescot, P. The New Definition of Oral Health and Relationship between Oral Health and Quality of Life. Chin. J. Dent. Res. Off. J. Sci. Sect. Chin. Stomatol. Assoc. 2017, 20, 189-192.

13. Carson, S.J.; Edwards, M. Barriers to providing dental care for older people. Evid.-Based Dent. 2014, 15, 14-15. [CrossRef]

14. Göstemeyer, G.; Baker, S.R.; Schwendicke, F. Barriers and facilitators for provision of oral health care in dependent older people: A systematic review. Clin. Oral Investig. 2019, 23, 979-993. [CrossRef]

15. Kiyak, H.A.; Reichmuth, M. Barriers to and Enablers of Older Adults' Use of Dental Services. J. Dent. Educ. 2005, 69, 975-986. [CrossRef]

16. Chowdhry, N.; Aleksejūnienè, J.; Wyatt, C.; Bryant, R. Dentists' perceptions of providing care in long-term care facilities. J. Can. Dent. Assoc. 2011, 77, 21.

17. De Visschere, L.; van der Putten, G.J.; de Baat, C.; Schols, J.; Vanobbergen, J. The impact of undergraduate geriatric dental education on the attitudes of recently graduated dentists towards institutionalized elderly people. Eur. J. Dent. Educ. 2009, 13, 154-161. [CrossRef]

18. Kiyak, H.A.; Milgrom, P.; Ratener, P.; Conrad, D. Dentists' attitudes toward and knowledge of the elderly. J. Dent. Educ. 1982, 6, 266-273. [CrossRef]

19. Hatami, B.; Ahmady, A.E.; Khoshnevisan, M.H.; Lando, H.A. Senior dental student's attitudes toward older adults and knowledge of geriatric dental care in the Islamic Republic of Iran. East. Mediterr. Health J. 2014, 19, S172-S177. [PubMed]

20. Anehosur, G.V.; Nadiger, R.K. Evaluation of understanding levels of Indian dental students' knowledge and perceptions regarding older adults. Gerodontology 2010, 29, 1215-1221. [CrossRef] [PubMed]

21. Moreira, A.N.; Rocha, E.S.; Popoff, D.A.; Vilaça, E.L.; Castilho, L.S.; de Magalhães, C.S. Knowledge and atti-tudes of dentists regarding aging and the elderly. Gerodontology 2012, 29, e624-e631. [CrossRef] [PubMed]

22. Bots-VantSpijker, P.C.; Vanobbergen, J.N.; Schols, J.M.; Schaub, R.M.; Bots, C.P.; de Baat, C. Barriers of delivering oral health care to older people experienced by dentists: A systematic literature review. Community Dent. Oral Epidemiol. 2014, 42, 113-121. [CrossRef]

23. Petersen, P.E.; Yamamoto, T. Improving the oral health of older people: The approach of the WHO Global Oral Health Programme. Community Dent. Oral Epidemiol. 2005, 33, 81-92. [CrossRef]

24. Nitschke, I.; Hahnel, S.; Jockusch, J. Health-Related Social and Ethical Considerations towards the Utiliza-tion of Dental Medical Services by Seniors: Influencing and Protective Factors, Vulnerability, Resilience and Sense of Coherence. Int. J. Environ. Res. Public Health 2021, 19, 2048. [CrossRef] [PubMed]

25. Xavier, I.; Ettinger, R.L.; Proença, L.; Botelho, J.; Machado, V.; Rua, J.; Delgado, A.S.; Mendes, J.J. Geriatric Dentistry Curriculum in Six Continents. Int. J. Environ. Res. Public Health 2020, 17, 4682. [CrossRef] [PubMed]

26. Kossioni, A.; McKenna, G.; Müller, F.; Schimmel, M.; Vanobbergen, J. Higher education in Gerodontology in European Universities. BMC Oral Health 2017, 17, 71. [CrossRef] [PubMed]

27. Bots-VantSpijker, P.C.; Bruers, J.J.M.; Bots, C.P.; de Visschere, L.M.J.; Schols, J.M.G.A. Dentists' opinions on knowledge, attitudes, and barriers in providing oral health care to older people living independently in the Netherlands and Flanders (Belgium). BDJ Open 2017, 3, 17020. [CrossRef] [PubMed]

28. Bots-VantSpijker, P.C.; Bruers, J.J.; Bots, C.P.; Vanobbergen, J.N.; de Visschere, L.M.; de Baat, C.; Schols, J.M. Opinions of dentists on the barriers in providing oral health care to community-dwelling frail older people: A questionnaire survey. Gerodontology 2016, 33, 268-274. [CrossRef]

29. Ettinger, R.L. A 30-year review of a geriatric dentistry teaching program. Gerodontology 2012, 29, e1252-e1260. [CrossRef] [PubMed]

30. Hebling, E.; Mugayar, L.; Dias, P.V. Geriatric dentistry: A new specialty in Brazil. Gerodontology 2007, 24, 177-180. [CrossRef]

31. De Visschere, L.M.; Vanobbergen, J.N. Oral health care for frail elderly people: Actual state and opinions of dentists towards a well-organized community approach. Gerodontology 2006, 23, 170-176. [CrossRef]

32. Nochajski, T.H.; Waldrop, D.P.; Davis, E.L.; Fabiano, J.A.; Goldberg, L.J. Factors That Influence Dental Students' Attitudes About Older Adults. J. Dent. Educ. 2009, 73, 95-104. [CrossRef] [PubMed]

33. Lovell, M. Caring for the elderly: Changing perceptions and attitudes. J. Vasc. Nurs. 2006, 24, 22-26. [CrossRef] [PubMed]

34. Fabiano, J.A.; Waldrop, D.P.; Nochajski, T.H.; Davis, E.L.; Goldberg, L.J. Understanding Dental Students' Knowledge and Perceptions of Older People: Toward a New Model of Geriatric Dental Education. J. Dent. Educ. 2005, 69, 419-433. [CrossRef] [PubMed] 